\title{
Social media adoption among small and medium-sized Greek hotels: a survey about its antecedents and its impact on performance outcomes
}

\section{Maria Spita, Eirini Peitzika* and Sofia Chatzi}

\author{
School of Social Sciences, \\ Hellenic Open University, \\ Patras, Greece \\ Email: mariaspita@yahoo.gr \\ Email: peitzika@aueb.gr \\ Email: hatsof@aueb.gr \\ *Corresponding author
}

\begin{abstract}
The use of social media in the hotel industry comprises a great challenge for marketing executives. The primary purpose of this study is to examine the use of social media (SM) among hotel firms, the role of organisational characteristics in SM adoption, and then the impact of SM adoption level on hotel performance outcomes. Using a sample of 60 small and mid-sized hotels located in Crete Island, Greece, we collected data through a questionnaire designed for hotel managers. The findings revealed that hotels are increasingly adopting social media. The results also indicated that the degree of previous experience and the satisfaction from the use of SM are highly related to SM adoption, while hotel size and hotel rating do not have a significant effect on social media adoption. Also, the adoption level of social media is an effective determinant of performance benefits. Managerial implications are being provided for tourism marketing and for hoteliers who want to adopt social media marketing tools.
\end{abstract}

Keywords: social media adoption; social media marketing; SMEs' performance; technology-organisation-environment; TOE; hotel industry.

Reference to this paper should be made as follows: Spita, M., Peitzika, E. and Chatzi, S. (2020) 'Social media adoption among small and medium-sized Greek hotels: a survey about its antecedents and its impact on performance outcomes', Int. J. Decision Sciences, Risk and Management, Vol. 9, Nos. 1/2, pp.23-54.

Biographical notes: Maria Spita is an MBA (Master in Business Administration) graduate of the Hellenic Open University. She completed her Bachelor's degree in Mass Media and Communication at National and Kapodistrian University of Athens and has attended educational programs and seminars regarding marketing, sales techniques, public relations and advertising. She works in the Municipality of Rethymnon-Greece, as A Chief Secretary of the Mayor for the past ten years and is the owner of a medium-sized accommodation business. Her research interests include tourism, travel and hospitality.

Eirini Peitzika holds a PhD from the Department of Marketing of the Athens University of Economics and Business in Greece. She has taught courses in marketing management, strategic management, human resource management, agricultural marketing and consumer behaviour at Hellenic Open University, 
Greece and Agricultural University of Athens, Greece in post-graduate and master degree programs. She has also sixteen years working experience in both private and public sector and she has also been involved in various projects and research programs funded by the EU. She has published in the field of marketing, advertising, tourism and biofuels. Her research interests lie in the areas of marketing management, tourism marketing and consumer behaviour.

Sofia Chatzi ( $\mathrm{PhD}$, Department of Management Science and Technology, Athens University of Economics and Business, Greece) is an organisational occupational psychologist and currently a member of the Adjunct Academic Staff of the Hellenic Open University, Patras, Greece. She teaches courses in organisational behaviour/psychology, management, human resources management, marketing management, economic psychology, strategic management, and management of multinational corporations at the Hellenic Open University, Patras, Greece and Athens University of Economics and Business, Greece in undergraduate and post-graduate level. She has published in the field of organisational behaviour/psychology, human resources management and economic psychology. Her current research interests include team-based employee selection, creativity and innovation, job insecurity, talent management, safety climate and safety performance, workplace mediation, economic and consumer behaviour.

\section{Introduction}

The incorporation of information and communication technologies (ICTs) into business has primarily altered the way we perceive business and marketing strategies (Porter, 2001). ICTs have radically changed the way customers have access to information and communicate with each other, while they have positively influenced the way companies interact and integrate with them, too (O'Conor, 2010). Today, more and more businesses adopt more interactive and dynamic applications, where users not only read the content provided to them but also actively contribute to the development of the content by sharing photos, ideas, videos, comments and experiences (Saravanakumar and Sugantha-Lakshmi, 2012). The prolonged use of ICTs globally has substantially affected the tourism businesses and destinations by helping them to enhance their competitiveness (Buhalis, 1993) and be successful. In a similar vein, more and more tourism theorists have drawn attention to social media strategies employed by travel and tourism industry (Neuhofer et al., 2014), and have pointed out the contribution of social media as a strategic and operational tool for marketing purposes (Inversini and Masiero, 2014).

Consumers that have a bigger emotional engagement to social media normally spread more positive comments for products or services (Chu and Kim, 2011). Word of mouth (wom), and the most recently concept of 'e-wom' is one of the most significant determinants of evaluating a service prior to its consumption (Litvin et al., 2008). The huge penetration of ICTs technologies and social media in consumers' lives certainly influences not only customer knowledge and consumers' perceptions towards the brand (e.g., Sigala, 2011; Goyette et al., 2010), but also influences consumers' actual buying behaviour. Consumers use social media to interact with industry suppliers and to gain information about products they are interested in. Furthermore, they consider social media a significant source of becoming aware of new offerings. The vast majority of consumers actively seek and read online reviews before making a purchase decision, as 
they perceive this kind of information as being more reliable compared to any other information delivered to them by other sources (Foux, 2006; Filieri and McLeay, 2013). Furthermore, social media are also linked to higher levels of buying intentions and higher potential to change consumers' attitudes towards a brand.

In travellers' market, social media has introduced major changes to the way travellers have access to information, book journeys and circulate travelling experiences (Xiang and Gretzel, 2010; Viglia et al., 2016; Varkaris and Neuhofer, 2017). Nowadays, travellers are more sophisticated and actively seek more travel-related information and reviews from other travellers before purchasing a travel service. As such, online reviews are considered one of the most reliable sources of information in travel and tourism (Xiang et al., 2015). As noted by Bahja et al. (2018), online reviews have emerged as the most significant determinant for cruise customers in their decision-making process. It is also common among travellers not to trust hotels with a review score below 4 stars and research has provided evidence of a negative relationship between a negative online review and online hotel booking intentions (Sparks and Browning, 2011). Eventually, the growth of virtual travel communities and travel review sites, such as TripAdvisor and Travelocity, where customers communicate their experiences and opinions for every travel service they have consumed, is of paramount importance to travellers that are sensitive to high levels of cognitive effort and uncertainty before making a travel decision (Wang et al., 2017).

Thus, due to travellers' reliance on social media content to assess their buying decisions and support their need to co-create travel experiences (Buhalis and Sinatra, 2019), the engagement with social media by travel and tourism businesses is growing rapidly, while the latter has changed the way travel enterprises operate (Kapiki, 2012). Although there has been a relatively slow adoption of ICTs from travel enterprises (Buhalis, 2003), destination marketing organisations (Mistilis et al., 2014), tourism companies (Baghirov et al., 2019) and in particular hotels are increasingly incorporating social media strategies as an integral element of their marketing and communication plans. Social media is considered a great marketing tool and presents hotels with significant challenges for brand growth and business development (Noone et al., 2011). The use of social media is considered to be inevitable for small- and medium-sized hotels in order to survive and become successful in the competitive tourism marketplace (Law et al., 2010; Spencer et al., 2012; Inversini and Masiero, 2014). Hence, a great challenge for tourism and hospitality professionals is the effective shift from classical marketing practices to online, social media and digital marketing in order their companies to adjust to travellers' needs for more information and interaction. Social media provides hotels an excellent opportunity to communicate and interact with customers, while offering accurate, real-time and personalised information long before they make the actual purchasing decision. Lastly, social media can also lower the bargaining power of intermediaries in the hotel industry, such as tour operators or tourism agencies, for reaching customers (Buhalis and Law, 2008).

Although there is a huge research effort to imprint the benefits derived from SM use, there is a dearth of research providing evidence regarding the factors affecting the degree of SM adoption by small and medium hotels and then whether the degree of SM adoption has an effect or not on the organisational performance. All the above inspired us to examine the degree of social media platforms adoption for marketing purposes in the hotel industry and especially, the factors that have an effect on this degree of SM 
adoption. Finally, we try to investigate the role of SM adoption in two major elements of hotel performance, namely financial and non-financial performance.

\section{Literature review}

\subsection{Definition and implications of social media}

According to Statista (2018), in the second quarter of 2018 the total number of social media users was 3.297 billion people worldwide, which corresponds to a penetration rate of $43 \%$ in a total market of 4.087 billion internet users. The huge penetration and the mass adoption of social media platforms have become extremely important in services markets, and even more important in hospitality and tourism.

Nowadays, more than ever, the traditional channels of communications as sources of information and communication have given their place to new platforms of participative web or social media (Constantinides, 2009). Though the use of social media has emerged as a dynamic component of marketing strategy in modern businesses, a lot of different conceptualisations and definitions can be addressed in the relevant literature. Social media is the outcome of information and communication technologies revolution and can be defined as "...a group of Internet-based applications that build on the ideological and technological foundations of Web 2.0 platform, and allow the creation and exchange of User Generated Content" [Kaplan and Haenlein, (2010), p.61]. Mayfield (2006) states that SM is "...about sharing ideas, cooperating and collaborating to create art, thinking and commerce, vigorous debate and discourse, finding people who might be good friends, allies and lovers" (p.07). In the same vein, social media cannot be considered a passive content but a dynamic interface where many users can communicate, create, and post and share their content (Sigala, 2011; Gupta and Brooks, 2013). The content transmitted through social media platforms encompasses online reviews, recommendations, information sharing, thoughts, experiences, stories, photographs, videos and many others that mainly affects travel and tourism industry (Cantallops and Salvi, 2014).

Social media definition contains a lot of different applications, tools and techniques (Kaplan and Haenlein, 2010) with many different classifications addressed in the literature. Each social media platform bears its unique characteristics and is supposed to serve different social services. In the present study, we carefully selected those social media platforms that are considered more applicable to the hotel industry and are more frequently used by hotel customers. We excluded from our analysis the virtual social worlds and the visual game worlds as their applicability in hospitality industry is relatively low. We also included specialised social media platforms that are exclusively used in travel and tourism industry, like TripAdvisor.

Social media provide hotel managers with many opportunities to effectively implement different functions of their organisations, including product distribution, promotion and communication, business management, market research, marketing and sales (Kietzmann et al., 2011; Leung et al., 2013). In particular, social media is undoubtedly considered a substantial instrument for strategic marketing, communication and selling activities in hospitality industry (Munar, 2011; Kumar et al., 2013; Leung et al., 2015). Hotels can use SM for a plethora of marketing implications, such as building and managing customer relationships, establishing a communication pathway 
with tourists for marketing and selling purposes, managing positive and negative comments, advertising and implementing promotional activities (Kim and Ko, 2012), providing information about hotel products and services, collecting market information (Constantinides, 2009), developing new tourist services (Culnan et al., 2010), and managing hotel online reputation.

\subsection{Social media adoption and benefits in hotel industry}

Research has shown that the adoption of SM yields substantial benefits for organisations. Marketers have the opportunity not only to transmit information about a product or service but also conduct marketing research and receive useful feedback from customers while monitoring travel reviews and comments for better understanding of their needs, preferences, attitudes and buying behaviors (Leung et al., 2013). Consumers' feedback provides the opportunity to tourism organisations to customise their marketing and sales efforts and provide personalised and specialised services that satisfy individual specific needs. Alongside, other benefits identified in the relevant literature include the enhancement of corporate image (Neti, 2011), the building and enhancement of global brand awareness, the strengthening of brand equity, the development of a unique brand identity, the augmentation of e-WOM positive communication (Trusov et al., 2009; Ashley and Tuten, 2015), the reduction of marketing costs (Molla and Heeks, 2007), the increase in purchase intentions (Colliander and Dahlén, 2011), the upgrade of search-engine rankings, and the increased traffic in hotel's official website (Lebherz, 2011). Social media platforms can greatly direct customers to hotels' official websites, where they can directly book their stay instead of using an intermediary (e.g., tour operator) to book the hotel for them (Jeong et al., 2003), thus, reducing hotel companies' reliance on intermediaries (Minghetti and Buhalis, 2010). Hoteliers can also use social media tools for online sales, especially when they are integrated with online traditional media (e.g., hotel's website) (Inversini and Masiero, 2014).

Undoubtedly, the focus of communication has moved from delivering information to building relationships with customers (Drury, 2007). Social media tools offer unprecedented opportunities to firms for interaction with customers, while building, maintaining and strengthening relationships with customers in some cases is achieved without requiring a substantial financial investment (Kim and Ko, 2012; Chikandiwa et al., 2013).

In addition, social media is regarded as a cost-effective way for hotels to reach masses of geographically dispersed travellers (Buhalis, 2003). The interactive nature of social media platforms provides firms and sales departments with real-time feedback from customers that contribute to effectively meeting the needs of their customers and identifying new segments with high selling potential by hotels (Liang and Turban, 2011). Another useful gain that derives from social media deployment is its contribution to pricing strategy as it provides insight into optimising pricing strategy (Noone et al., 2011). Moreover, the use of social media enables hotel managers to facilitate promotion by providing online special offers and rewards to their customers. Finally, by applying social media tools hotel managers can ensure loyalty and customer retention (Gilbert, 1996; Lee-Kelley et al., 2003).

Given the competitive framework of tourism industry, in order for social media marketing activities to prove beneficial for hotels, firstly, it is imperative that hotels 
realise that social media should be a fully integrated element of their marketing and communication strategy in compliance with their traditional media plans, and secondly, should be implemented following a carefully designed social media strategy, which includes carefully selecting social media platforms tailored to the objectives a hotel company wants to accomplish, and the specific audiences that wish to serve; otherwise, it would be an useless tool with only short-term results for businesses (Andzulis et al., 2012).

The perceived reliability of SM, its unique characteristics, its almost catholic adoption by individual consumers, its increased influence on consumer buying behaviour and its undoubtable benefits for organisations, have led hotels to adopt and utilise them either as a key component of their marketing strategy or as a complement to other marketing tools. Undoubtedly, an increasing number of hotels have adopted numerous SM platforms simultaneously in order to gain as many benefits they can get from such an extended use (Michaelidou et al., 2011; Paraskevas et al., 2011).

Although organisations have recognised the potential of SM, the adoption of social media tools in some cases is not without obstacles (Radwan, 2016). Marketing managers often do not fully appreciate the efficiency of social media, while the main frontiers for a firm's inability to integrate them in its marketing strategy are also the scarcity of resources and managers' struggle to develop adequate skills and technical expertise (Venkatesh and Davis, 2000; Michaelidou et al., 2011). Another important reason for this unwillingness to adopt social media tools for marketing purposes is that marketers have difficulty measuring social media effectiveness in achieving marketing objectives (Pradiptarini, 2011; Fischer, 2009).

Moreover, the resources and capabilities constraints of small travel and tourism enterprises (Spencer et al., 2012) and also the perception that small-sized organisations cannot benefit from their use inhibit small firms' social media deployment. The above perception is reinforced as most of the research on social media literature has been conducted in large organisations (Gallaugher and Ransbotham, 2011; Bogea and Brito, 2018). Less research has examined the adoption of social media in small- and medium-sized organisations (Wamba and Carter, 2014; He et al., 2015) and the potential benefits of social media use in the travel and tourism industry (Danias and Kavoura, 2013). Furthermore, the impact of social media adoption on hotel performance has not been empirically investigated yet (Parveen, 2012; Odoom et al., 2017).

Given that social media is an ICT technology, its adoption can be described as any other technology adoption. Although many researchers have examined a lot of factors related to ITCs adoption process in the tourism context, there is relatively little available evidence that unveils the facilitators of social media adoption in a hotel context. Studies in social media adoption are an emerging research topic with little empirical results, especially in hospitality context. It is also common that a stream of research in technology adoption theories have been focused on exploring the initial decision of a firm to adopt a new form of technology while others do not. Fewer research studies investigated firm's decision to continually use these technologies to a great extent. In addition, research related to technology adoption theories have mostly examined technology adoption at individual level, while the research at organisational level is rather limited (Yu and Tao, 2009).

Lastly, the adoption of ICTs, and, more specifically, that of social media platforms, and the factors that stimulate their usage are more than relevant for countries and regions 
that are less technologically developed. In the tourism sector, the technological readiness of a country or a region is regarded as an indicator of its ability to effectively interact with customers (Minghetti and Buhalis, 2010) while affecting the image of the destination. Therefore, the need to explore the factors that accelerate ICTs adoption in the tourism industry is imperative, as the discussion will be beneficial to hotels and policymakers.

All the above gaps in research motivated us to further explore the use of social media as a marketing and communication tool in small and medium-sized hotels. The main objectives of this study are to:

a examine the importance of the different types of social media platforms that are employed for marketing purposes by hotels, as well as the current degree of adoption

b specify the criteria on which hotel managers select specific social media platforms

c determine the objectives for using social media tools

d investigate the factors that have a positive effect on social media marketing adoption level

e explore the relationship between the level of social media adoption and hotel performance

Apart from the identification of social media behavior by small and medium-sized hotels based on adoption theories and social media literature we propose a model that explores the determinants of social media adoption and use taking into consideration that social media differ substantially compared to other technological innovations. In this study, we seek to examine the role of organisational characteristics (size, star rating, experience and satisfaction) of small and medium-sized hotels in the adoption level of social media. Our study contributes to social media literature in four ways: first, it furthers our knowledge of social media use for marketing activities in small and medium-sized hotels, second, it supplements technology adoption theory by testing the effect of additional determinants of social media adoption in hotels, third, it extends social media adoption literature by exploring the factors that determine the degree of this engagement in hospitality context and not by simply examining the factors that influence the initial decision whether to engage or not in social media marketing, and finally, it provides useful insight in academic researchers and practitioners regarding the impact of social media adoption on organisational performance.

\section{Conceptual development and hypotheses}

\subsection{Theoretical models in technology adoption}

Based on the view that social media adoption is a form of technology adoption, someone can find numerous theoretical approaches that try to illustrate factors for its adoption. The most widely recognised and used technology adoption models and the factors being employed to serve as determinants of technology adoption and use are (for a review see Oliveira and Martins, 2011): 
a the technology of adoption model (TAM) proposed by Davis (1989), which examines the role of perceived usefulness and perceived ease of use

b the technology of adoption model II (TAM2) proposed by Venkatesh and Davis (2000) that complements TAM model by considering image, subjective norm and experience as factors influencing technology adoption

c the theory of planned behaviour (TPB) (Ajzen, 1991)

d the diffusion of innovation (DoI) model developed by Rogers (2003) who stressed the importance of technological (e.g., compatibility, trialability) and organisational characteristics (e.g., size, support from management)

e the unified theory of acceptance and technology use (UTATU) proposed by Venkatesh et al. (2003)

f the technology-organisation-environment framework (TOE) supported by Tornatzky and Fleischer (1990) according to which technological, organisational and environmental factors, such as top management support, IT expertise, perceived benefits, availability of resources, firm size, competitive pressure, and government support, influence the acceptance and adoption of technology.

TAM, TPB and UTUAT models have been primarily used to examine individual-level technology adoption, while DoI and TOE are models mostly utilised in organisational contexts. Though, TOE has been regarded as a valuable framework to explain and predict technology adoption (Arpaci et al., 2012; Ndekwa and Katunzi, 2016) among organisations with a variety of technologies (e.g., Baker, 2012; Gangwar et al., 2015) compared with other adoption models.

Figure 1 The proposed model

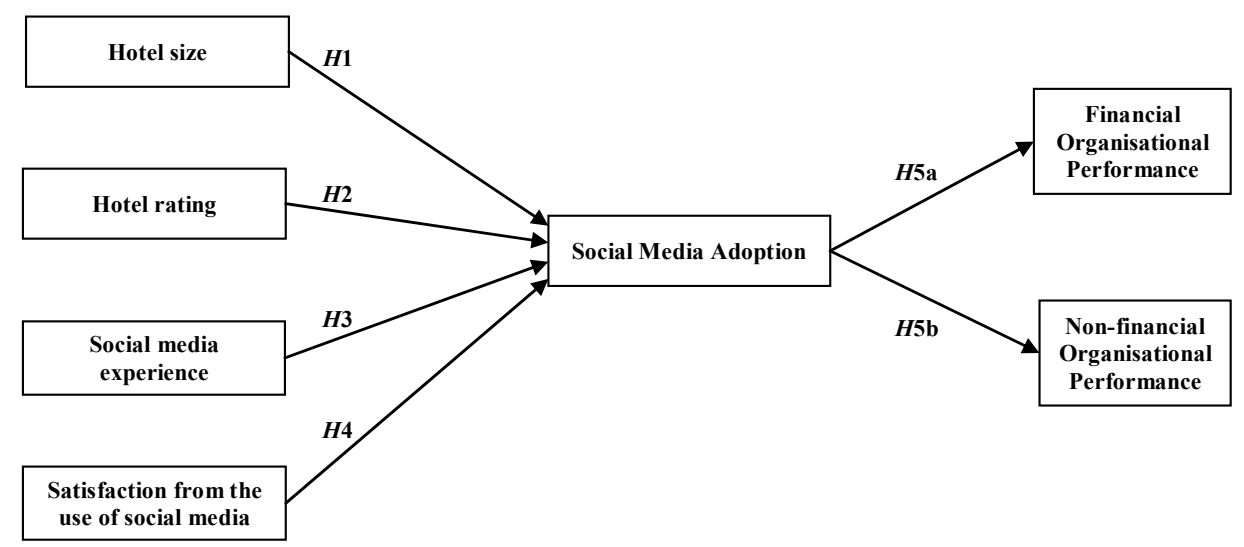

Drawing on extended TAM (Venkatesh and Davis, 2000), TOE framework (Tornatzky and Fleischer, 1990) and information technologies theories, a set of organisational-level determinants on social media adoption in hotels were tested, namely hotel size, star rating of the hotel, prior experience in the use of SM platforms, and managers' perceptions of 
the degree of their satisfaction with social media platforms used in their hotels for marketing purposes. More precisely, we tried to examine how the above factors directly influence the extent of social media use for marketing purposes by hotels, contrary to other research efforts that have examined the initial decision of hotels to accept and adopt or not social media platforms. After identifying the factors of social media adoption, we examined the influence of social media use on financial and non-financial organisational performance.

The proposed model is illustrated in Figure 1.

\subsection{Antecedents of social media adoption in hotels}

As discussed earlier, theories of technology adoption have identified organisational characteristics as key components of technology adoption. In the current study, we examine the effect of hotel size, star rating, experience and satisfaction from the use of social media.

\subsubsection{Hotel size}

The size of an organisation is regarded as a key predictor of technology adoption, since it enhances the likelihood of excess resources and it associates with an organisation's ability to successfully integrate the new technology in business strategy (Hackler and Saxton, 2007). Plenty of research findings have confirmed the effect of firm size on the decision to accept or reject a new technology (Shook et al., 2002; Zorn et al., 2011; Arpaci et al., 2012; Verheyden and Goeman, 2013). More specifically, studies focusing on social media adoption indicated that firm size significantly explains the adoption of social media by organisations (Litvin et al., 2008; Mandal and McQueen, 2012; Escobar-Rodriquez and Carvajal-Trujillo, 2013; Garrido-Moreno and Lockett, 2016). Although all the above studies have provided evidence of the relationship between organisation size and social media adoption, there is not enough indication of the role of the size of an organisation on the degree of social media use with the exception of Verheyden and Goeman (2013) who revealed that the intention of social media use is bigger in larger firms.

Larger organisations compared to SMEs have usually more and adequate resources to support social media use and to enable a higher degree of social media use (Rahab and Hartono, 2012). The availability of employees that are assigned with the task of the implementation and management of social media activities over time, along with the excess financial resources associated with larger organisations are supposed to be major aspects of organisation size that consequently affect social media adoption rate. On the other hand, having in mind the higher flexibility of smaller firms to adapt better to technological change, many scholars claim that smaller firms (Frambach and Schillewaert, 2002; McAfee, 2006) may be more able to adopt new technologies.

In line with previous studies that showed that smaller organisations have resource constraints and other barriers to technology adoption (Rahab and Hartono, 2012), we expected that smaller hotels are less likely to adopt social media for marketing purposes to a great extent. Therefore, we tested the following hypothesis:

Hypothesis 1 Hotel size has a significant positive effect on the degree of social media adoption. 


\subsubsection{Hotel rating}

Hotel rating is an indicator of service quality provided. In the current study, we tried to investigate whether the level of service quality has a positive effect on social media use. Nassar (2012) examined the relationship between hotel star ratings and social media use and concluded that hotels with higher star ratings are more likely to engage in social media activities. This finding can be explained by the fact that hotels with higher ratings are hotels that provide better quality and augmented services to travellers, therefore, are expected to have bigger availability of resources, greater expertise and willingness to respond to customers' needs.

Following the above findings, we wanted to examine whether a hotel star rating is associated with the degree of social media adoption. Thus, we examined the following hypothesis:

Hypothesis 2 Hotel rating has a significant positive effect on the degree of social media adoption.

\subsubsection{Social media experience}

Contrary to the original technology of adoption model (Davis, 1989), the enhanced TAM II model (Venkatesh and Davis, 2000) considers prior experience in technology as an element with a significant effect on attitudes, which subsequently impact the propensity of organisations to adopt this technology. Additionally, Michaelidou et al. (2011) report that experience, expertise and resource availability constitute the most common barriers in social media tools adoption among hotels. In the above reasoning, other researchers argue that a hotel's level of social media knowledge develops competencies that can induce firms to adopt and use additional technologies (Rogers, 2003; Kropczynski and Nah, 2011) perhaps because marketing managers anticipate reduced risks and effort associated with a more intense use (Gretzel et al., 2007). Hotel managers' perceptions regarding social media experience are a significant facilitator of the technology adoption process (Straub, 2009). As noted by Nikraftar and Hosseini (2016) prior knowledge is one of the most significant predictors of business opportunity recognition to grow business by tourism enterprises that influence the adoption of new innovations in travel and tourism industry.

Therefore, we supposed that increased levels of prior similar experience in social media tools can facilitate the incremental involvement and engagement with social media. Thus, the following hypothesis was tested:

Hypothesis 3 Hotel experience with social media tools has a significant positive effect on the degree of social media adoption.

\subsubsection{Satisfaction from the use of social media}

The perceived effectiveness or usefulness regarding the use of a technology influences the level of satisfaction from its use (Davis, 1989). A number of studies have demonstrated that higher levels of satisfaction lead to increased intentions towards the use of technologies at individual level (Chang, 2013; Park and del Pobil, 2013; Nikou and Economides, 2015) or increased technology usage (Khalil and Elkordy, 1999; Stone 
et al., 2007). When someone is satisfied, he/she feels a sense of contentment (Hernon and Whitman, 2001), and within the technology acceptance literature, satisfaction is regarded as an attitude toward the use of a technology. More specifically, satisfaction is an important driver of technology use in organisational settings.

Since there is no existing literature regarding the impact of an organisation's level of satisfaction with the existing social media use on the subsequent degree of technology adoption, we proposed that hotels that have a positive perception of the effectiveness and usefulness of social media use, as subjectively expressed by the general or marketing manager, are more likely to utilise these tools for marketing purposes. Therefore, we developed and tested the following hypothesis:

Hypothesis 4 Hotel's level of satisfaction with the existing social media use has a significant positive effect on the degree of social media adoption.

\subsubsection{The impact of social media on hotel performance}

In an organisational setting, the ultimate goal of social media use is the enhancement of organisational performance. A number of studies have investigated the role of various social media tools on organisational performance in various settings. Kwok and $\mathrm{Yu}$ (2013) and Rodriguez et al. (2014) have supported the relationship between Facebook use and sales performance, while Ainin et al. (2012, 2015) and Parveen et al. (2015) concluded that Facebook usage plays a significant role into both financial and non-financial performance. Based on Ainin et al. (2015) work, Odoom et al. (2017) confirmed that social media use among SMEs affects the two above dimensions of performance. Ferrer et al. (2013) concluded that social networks significantly influence financial, market and shareholder value performance (Stone et al., 2007). Almost all studies empirically support the impact of social media use on firm performance, while only a few studies do not (Ahmad et al., 2018). Though, little research has examined and supported the role of social media tools specifically on hotel performance (Tajvidi and Karami, 2017).

Following the work of other researchers, our final hypotheses were the following:

Hypothesis 5a The adoption of social media tools has a significant positive effect on hotel financial organisational performance.

Hypothesis $5 \mathrm{~b}$ The adoption of social media tools has a significant positive effect on hotel non-financial organisational performance.

\section{Methodology}

\subsection{Sample, data collection and measures}

An exploratory study was conducted with data gathered from small and medium-sized hotels that operate on the island of Crete in Greece and are members of the Hellenic Hoteliers Federation. We focused on hotels primarily from Crete, since Greece in general, along with some of its islands are considered the most visited tourist destinations 
in Europe (WTTC, 2018) and for one additional reason: to control for the interference of locational factor on hotel performance as Ham and her colleagues have suggested (2005). Thus, from the total of 60 hotels that agreed to take part in the survey $68.3 \%$ were small-sized hotels that employed less than 50 employees, while $25 \%$ were medium-sized hotels that had more than 51 employees. Since grading and classification of hotels area reliable indication of expected services and facilities standards, hotels that have been classified as tourist $\left(^{*}\right.$ ) (Wikipedia, 2018) were not included in the final sample as having the least potential of using social media platforms as a marketing tool. So, the target population of the study consisted of hotels from 3 to 5 stars. $41.7 \%$ of the hotels were classified as standard (**), and comfort $(* * *)$ hotels, whereas the rest 53.3 percent of the hotels were classified as first class $(* * * *)$ and luxury $(* * * * *)$ hotels. Concluding, the majority of the participants were general managers $(45 \%)$, whereas $30 \%$ of the sample were hotel owners and the rest $21.7 \%$ were marketing managers.

Our research hypotheses were tested by following a quantitative research approach. Due to a lack of archival data on organisations in question, we followed the key-informant method to collect information on organisational - level constructs (e.g., Seidler, 1974). General hotel managers, corporate-level hotel marketing managers and hotel owners were chosen to provide this information due to their specialised knowledge towards their organisations (Bagozzi et al., 1991; Garrido-Moreno and Lockett, 2016). So, a structured questionnaire was uploaded to Google Form application (https://www.google.com/forms/about) accompanied by a cover letter explaining the research objectives and administration details and then general, marketing managers and hotel owners were invited through e mails to follow the link to the survey and complete the questionnaire. Individual anonymity was assured. Two weeks later a reminder letter was sent to participants. Four weeks were needed for the responses to be collected.

The questionnaire consisted of two main parts. In part 1, participants were asked to record their immediate response to items that reflect the frequency in which their hotels use different social media platforms (i.e., Facebook, Twitter, etc.), the kind of social media analytics tools that hotels use, the criteria of choosing a social media platform over another and the main non-financial objectives derived from the use of social media platforms. In part 2, participants were surveyed on the constructs of interest namely social media adoption in their hotels, satisfaction from the use of social media, social media experience, financial and non-financial organisational performance (i.e., after the usage of social media platforms).

The frequency a hotel uses different social media platforms (i.e., Facebook, Twitter etc.) was measured on a 5-point Likert scale ranging from $1=$ never to $5=$ very often, whereas three items were used to measure the kind of social media analytic tools that a hotel use (Spita, 2017). Two multi-item measures for the assessment of the criteria of choosing a social media platform over another (6 items; sample criteria: 'importance of the platform', 'popularity', etc.) and the main non-financial objectives derived from the use of social media platforms (seven items; sample items: 'my hotel uses social media platforms to attract new customers', 'my hotel uses social media platforms to receive customer feedback on existing hotel's offers/services', etc.) were adapted from Ainin et al. (2015) and Odoom et al. (2017) and were measured on a 5-point Likert scale ranging from: 'not at all important' to 'very important'. 
A 5-point Likert scale ( $1=$ not at all/ 5=to a great extent) was used to measure social media adoption which was represented by an item derived from Siamagka et al. (2015) ('to what extent does your hotel currently use social media'). On the premise that satisfaction constitutes a reflection of the gratifications for continual usage of social media (see, Odoom et al., 2017), the hotel managers' level of satisfaction from the use of social media was assessed with one item ('I am satisfied with the use of social media in my hotel?' 1=very dissatisfied/ 5=very satisfied). For our research purposes, we tested the role of social media experience on social media adoption by asking the participants to respond to one question 'How long has your hotel been using social media as a marketing tool'. Social media experience was coded as $1=0-12$ months, $2=1-2$ years, $3=$ 3-4 years and $4=$ more than 5 years. Finally, non-financial organisational performance (i.e., after the usage of social media platforms) was measured with a 6-item scale adapted from Ainin et al. (2015) and Odoom et al. (2017) (sample items: 'the use of social media in my hotel has improved the visibility of the hotel', 'the use of social media in my hotel has increased the customer loyalty and retention'), whereas for the measurement of the financial organisational performance one item ('the use of social media in my hotel has increased sales') was derived from the 4-item measure of Ainin et al. (2015). Items were modified to fit the context of hotels. Both scales were measured on a 5-point scale ranging from $1=$ strongly disagree to $5=$ strongly agree. The Cronbach's $\alpha$ value for the non-financial organisational performance measure was .85 , which is well above the recommended .70 cut-off (Nunnally, 1978). All study data analyses were conducted with the use of SPSS version 24.

\section{Results}

\subsection{Social media platforms usage}

The participants of the study were asked about the frequency their hotels use different social media platforms. The majority of survey's participants indicated that their hotels use Facebook very often (55\%) while the $1.7 \%$ of the hotels do not use the Facebook platform as a marketing tool at all. Table 1 depicts different distribution of the percentages for Twitter, Linkedin, Pinterest, Youtube, Google+ and Foursquare. Specifically, these platforms seem to be never used as a marketing tool by a significant percent of hotels operating in Crete $(56.7 \%, 50 \%, 63.3 \%, 48.3 \%, 41.7 \%, 63.3 \%$ respectively), while the above platforms are frequently used by a minority of the hotels in our study $(6.7 \%, 3.3 \%, 5 \%, 3.3 \%, 13.3 \%, 3.3 \%$ respectively). 35 percent of the hotels do not use Instagram platform, whereas 21.7 percent of the hotels use the platform in question sometimes. Finally, TripAdvisor that constitutes an online travel site amassing reviews and opinions from travellers about worldwide experiences, accommodations, restaurants, airlines is considered a useful marketing tool for hotels (TripAdvisor, 2018). A percentage of $55 \%$ of the participants noted that their hotels utilise the TripAdvisor platform very often. In contrast, a percentage of $10 \%$ of the hotels hesitate in adopting the TripAdvisor platform for marketing purposes. 
Table 1 Social media platforms usage $(\mathrm{N}=60)$

\begin{tabular}{|c|c|c|}
\hline & Frequency & Percent (\%) \\
\hline \multicolumn{3}{|c|}{ Facebook platform } \\
\hline Never & 1 & 1.7 \\
\hline Rarely & 5 & 8.3 \\
\hline Sometimes & 7 & 11.7 \\
\hline Often & 14 & 23.3 \\
\hline Very often & 33 & 55 \\
\hline \multicolumn{3}{|l|}{ Twitter platform } \\
\hline Never & 34 & 56.7 \\
\hline Rarely & 9 & 15 \\
\hline Sometimes & 6 & 10 \\
\hline Often & 7 & 11.7 \\
\hline Very often & 4 & 6.7 \\
\hline \multicolumn{3}{|c|}{ Linkedin platform } \\
\hline Never & 30 & 50 \\
\hline Rarely & 12 & 20 \\
\hline Sometimes & 9 & 15 \\
\hline Often & 7 & 11.7 \\
\hline Very often & 2 & 3.3 \\
\hline \multicolumn{3}{|c|}{ Pinterest platform } \\
\hline Never & 38 & 63.3 \\
\hline Rarely & 7 & 11.7 \\
\hline Sometimes & 8 & 13.3 \\
\hline Often & 4 & 6.7 \\
\hline Very Often & 3 & 5 \\
\hline \multicolumn{3}{|c|}{ Instagram platform } \\
\hline Never & 21 & 35 \\
\hline Rarely & 6 & 10 \\
\hline Sometimes & 13 & 21.7 \\
\hline Often & 9 & 15 \\
\hline Very often & 11 & 18.3 \\
\hline \multicolumn{3}{|c|}{ Youtube platform } \\
\hline Never & 29 & 48.3 \\
\hline Rarely & 11 & 18.3 \\
\hline Sometimes & 10 & 16.7 \\
\hline Often & 8 & 13.3 \\
\hline Very often & 2 & 3.3 \\
\hline
\end{tabular}


Table 1 Social media platforms usage $(\mathrm{N}=60)$ (continued)

\begin{tabular}{lcc}
\hline & Frequency & Percent (\%) \\
\hline Google+ platform & 25 & 41.7 \\
Never & 8 & 13.3 \\
Rarely & 9 & 15 \\
Sometimes & 10 & 16.7 \\
Often & 8 & 13.3 \\
Very often & & \\
Foursquare platform & 38 & 63.3 \\
$\quad$ Never & 14 & 23.3 \\
Rarely & 4 & 6.7 \\
Sometimes & 2 & 3.3 \\
Often & 2 & 3.3 \\
Very often & & \\
TripAdvisor platform & 6 & 10 \\
Never & 4 & 6.7 \\
Rarely & 4 & 6.7 \\
Sometimes & 13 & 21.7 \\
Often & 33 & 55 \\
Very often & 60 & 100 \\
\hline Total & &
\end{tabular}

\subsection{Social media analytics tools usage}

Participants were asked which of the social media analytics tools have been used to monitor the social media presence of their hotels. In our study, $40 \%$ of the businesses utilise a free analytic tool, $30 \%$ have adopted tools that are available to all business users for free and only $6.7 \%$ are willing to pay for services like these (see Table 2).

Table 2 Social media analytics tools usage $(N=60)$

\begin{tabular}{lcc}
\hline & Frequency & Percentage (\%) \\
\hline Free AT & 24 & 40 \\
Platform's AT & 18 & 30 \\
Paid AT & 4 & 6.7 \\
N/A & 14 & 23.3 \\
\hline Total & 60 & 100 \\
\hline
\end{tabular}

Note: AT - analytic tools; N/A - no answer.

\subsection{Criteria of choosing a social media platform}

In order to identify the main criteria that the 60 hotels of the sample consider most important when choosing a social media platform over another, managers were asked to 
respond to six criteria namely importance of the platform, its popularity, functionality and cost, its ability to attract a specific target group or groups and the platforms that are used by the competitors to reach customers (see Table 3 ). The majority of the sample claimed that the importance of the platform $(55 \%)$ and its popularity $(78.3 \%)$ are considered by hotel managers as very important elements of choosing a social media platform over another. On the other hand, a considerable percentage (35\% and $38.3 \%$ respectively) of the sample accepts that a platform's ability to attract a specific target group of customers and the functionality of the platform constitute moderately important components of rejecting a social media platform.

Table 3 Criteria of choosing a social media platform $(\mathrm{N}=60)$

\begin{tabular}{|c|c|c|}
\hline & Frequency & Percent $(\%)$ \\
\hline \multicolumn{3}{|c|}{ Importance of the SM platform } \\
\hline Not at all important & 0 & 0 \\
\hline Slightly important & 2 & 3.3 \\
\hline Moderately important & 16 & 26.7 \\
\hline Important & 4 & 6.7 \\
\hline Very important & 33 & 55 \\
\hline $\mathrm{N} / \mathrm{A}$ & 5 & 8.3 \\
\hline \multicolumn{3}{|c|}{ Popularity of the SM platform } \\
\hline Not at all important & 0 & 0 \\
\hline Slightly important & 0 & 0 \\
\hline Moderately important & 9 & 15 \\
\hline Important & 1 & 1.7 \\
\hline Very important & 47 & 78.3 \\
\hline $\mathrm{N} / \mathrm{A}$ & 3 & 5 \\
\hline \multicolumn{3}{|c|}{ Target users/ groups of the SM platform } \\
\hline Not at all important & 0 & 0 \\
\hline Slightly important & 0 & 0 \\
\hline Moderately important & 21 & 35 \\
\hline Important & 5 & 8.3 \\
\hline Very important & 27 & 45 \\
\hline N/A & 7 & 11.7 \\
\hline \multicolumn{3}{|c|}{ Functionality of the SM platform } \\
\hline Not at all important & 2 & 3.3 \\
\hline Slightly important & 0 & 0 \\
\hline Moderately important & 23 & 38.3 \\
\hline Important & 12 & 20 \\
\hline Very important & 17 & 28.3 \\
\hline N/A & 6 & 10 \\
\hline
\end{tabular}

Note: N/A - no answer. 
Table 3 Criteria of choosing a social media platform $(\mathrm{N}=60)$ (continued)

\begin{tabular}{lcc}
\hline & Frequency & Percent (\%) \\
\hline SM Platform usage by the competitors & 5 & \\
Not at all important & 2 & 8.3 \\
Slightly important & 21 & 3.3 \\
Moderately important & 8 & 35 \\
Important & 19 & 13.3 \\
Very important & 5 & 31.7 \\
N/A & & 8.3 \\
Cost of the SM platform & 6 & \\
Not at all important & 1 & 10 \\
Slightly important & 17 & 1.7 \\
Moderately important & 12 & 28.3 \\
Important & 19 & 20 \\
Very important & 5 & 31.7 \\
N/A & & 8.3 \\
\hline
\end{tabular}

Note: N/A - no answer.

Finally, those platforms that are used by the competitors to reach customers and the cost accompanying each platform contribute to managers' decision to choose a social media platform over another. A great percentage of the respondents stated that competitors and the platforms they use for marketing purposes are considered very important $(31.7 \%)$ and another percentage of the sample $(35 \%)$ reported that this criterion is moderately important. Furthermore, the cost of a social media platform plays a role, although controversial, in their decisions to use a platform. There is a percentage of the sample that claimed that the cost is a very important element (31.7\%), whereas a significant percentage of the sample considered it as moderately important $(28.3 \%)$.

\subsection{Non-financial objectives from the social media platforms usage}

The main non-financial objectives from the social media platforms usage are depicted in Table 4 . There were $46.7 \%$ of respondents suggesting that the usage of social media platforms help hotels to acquire new customers and sustain the ones they have. By initiating effective digital marketing tools hotels can communicate with customers instantly and easily (53.3\%) and nurture stronger and more direct relationships with them $(55 \%)$. Through social media platforms not only can hotels advertise and promote their offers $(43.3 \%)$, they can also receive customer feedback on existing offers and services $(56.7 \%)$. While it is true that social media platforms are effective tools in promoting products and services, it is also as important to use these channels effectively in order to strengthen customer loyalty. So, $46.7 \%$ of the respondents stated that one of the most important objectives of encompassing social media into their marketing endeavours is the opportunity provided to hotels to enhance customer loyalty given the amount of people using social media platforms every day. Finally, since branding is significant for the success of any hotel, the creation and communication of a hotel's brand image online is 
considered very important by the majority of managers that participated in this survey (61.7\%).

Table 4 Non-financial objectives from the social media platforms usage $(\mathrm{N}=60)$

\begin{tabular}{|c|c|c|}
\hline & Frequency & Percent (\%) \\
\hline \multicolumn{3}{|l|}{ Attract new customers } \\
\hline Not at all important & 1 & 1.7 \\
\hline Slightly important & 1 & 1.7 \\
\hline Moderately important & 6 & 10 \\
\hline Important & 21 & 35 \\
\hline Very important & 28 & 46.7 \\
\hline $\mathrm{N} / \mathrm{A}$ & 3 & 5 \\
\hline \multicolumn{3}{|c|}{ Communicate with customers } \\
\hline Not at all important & 1 & 1.7 \\
\hline Slightly important & 1 & 1.7 \\
\hline Moderately important & 12 & 20 \\
\hline Important & 12 & 20 \\
\hline Very important & 32 & 53.3 \\
\hline N/A & 2 & 3.3 \\
\hline \multicolumn{3}{|c|}{ Nurture relationships with customers } \\
\hline Not at all important & 1 & 1.7 \\
\hline Slightly important & 2 & 3.3 \\
\hline Moderately important & 2 & 3.3 \\
\hline Important & 16 & 26.7 \\
\hline Very important & 33 & 55 \\
\hline N/A & 6 & 10 \\
\hline \multicolumn{3}{|c|}{ Advertise and promote hotel offers } \\
\hline Not at all important & 1 & 1.7 \\
\hline Slightly important & 2 & 3.3 \\
\hline Moderately important & 11 & 18.3 \\
\hline Important & 16 & 26.7 \\
\hline Very important & 26 & 43.3 \\
\hline N/A & 4 & 6.7 \\
\hline \multicolumn{3}{|c|}{ Receive customer feedback on existing hotel's offers/services } \\
\hline Not at all important & 1 & 1.7 \\
\hline Slightly important & 2 & 3.3 \\
\hline Moderately important & 6 & 10 \\
\hline Important & 13 & 21.7 \\
\hline Very important & 34 & 56.7 \\
\hline N/A & 4 & 6.7 \\
\hline
\end{tabular}

Note: N/A - no answer. 
Table 4 Non-financial objectives from the social media platforms usage $(\mathrm{N}=60)$ (continued)

\begin{tabular}{lcc}
\hline & Frequency & Percent (\%) \\
\hline Strengthen customers' loyalty & & \\
Not at all important & 1 & 1.7 \\
Slightly important & 1 & 1.7 \\
Moderately important & 6 & 10 \\
Important & 19 & 31.7 \\
Very important & 28 & 46.7 \\
N/A & 5 & 8.3 \\
Create and communicate hotel's brand image online & & \\
Not at all important & 0 & 0 \\
Slightly important & 1 & 1.7 \\
Moderately important & 7 & 11.7 \\
Important & 10 & 16.7 \\
Very important & 37 & 61.7 \\
N/A & 5 & 8.3 \\
\hline
\end{tabular}

Note: N/A - no answer.

Table 5 Means, standard deviations, and correlations among the variables of interest $(\mathrm{N}=60)$

\begin{tabular}{|c|c|c|c|c|c|c|c|c|c|c|}
\hline & & Mean & $S D$ & 1 & 2 & 3 & 4 & 5 & 6 & 7 \\
\hline 1 & Hotel rating & 1.56 & .50 & 1 & $.29 *$ & .16 & .00 & .13 & -.03 & -.08 \\
\hline 2 & Hotel size & 1.27 & .44 & & 1 & .07 & .03 & .06 & $-.22^{\dagger}$ & $-.29 *$ \\
\hline 3 & Social media experience & 2.85 & .98 & & & 1 & $.27^{*}$ & $.40^{* *}$ & .12 & .18 \\
\hline 4 & $\begin{array}{l}\text { Satisfaction from the use of } \\
\text { social media }\end{array}$ & 3.15 & 1.00 & & & & 1 & $.67 * *$ & $.53 * *$ & $.25^{\dagger}$ \\
\hline 5 & Social media adoption & 3.25 & 1.24 & & & & & 1 & $.43 * * *$ & $.43 * * *$ \\
\hline 6 & $\begin{array}{l}\text { Non-financial organisational } \\
\text { performance }\end{array}$ & 23.57 & 4.20 & & & & & & 1 & $.58 * *$ \\
\hline 7 & $\begin{array}{l}\text { Financial organisational } \\
\text { performance }\end{array}$ & 3.87 & .89 & & & & & & & 1 \\
\hline
\end{tabular}

Note: ${ }^{\dagger} p<.10 ; * p<.05 ;{ }^{* *} p<.01 ; * * * p<.001$.

\subsection{Descriptive statistics and correlation analysis}

We used correlational analysis to test the hypothesised relationships between social media adoption and financial organisational performance and between social media adoption and non-financial organisational performance. Table 5 provides means, standard deviations, and zero-order correlations among the study variables. Firstly, correlation analysis showed that social media adoption is positively related to both financial and non-financial organisational performance $(\mathrm{r}=.43, \mathrm{p}<.001 ; \mathrm{r}=.43, \mathrm{p}<.001$ respectively). As a result, $\mathrm{H} 5 \mathrm{a}$ and $\mathrm{H} 5 \mathrm{~b}$ are supported. Furthermore, results revealed that 
none of the predictor variables of hotel size and hotel rating is significantly associated with social media adoption $(\mathrm{r}=.06, \mathrm{p}>.05 ; \mathrm{r}=.13, \mathrm{p}>.05$ respectively). So, $\mathrm{H} 1$ and $\mathrm{H} 2$ are rejected. Instead, hotel experience with social media platforms in the past and satisfaction from the use of them are significant predictors of social media adoption $(\mathrm{r}=$ $.40, \mathrm{p}<.01 ; \mathrm{r}=.67, \mathrm{p}<.01$ respectively). Thus, $\mathrm{H} 3$ and $\mathrm{H} 4$ are supported. This analysis was an initial step to test the $\mathrm{H} 1, \mathrm{H} 2, \mathrm{H} 3$ and $\mathrm{H} 4$ before moving to a further analysis of the aforementioned hypothesised relationships.

\subsection{Hierarchical regression analysis}

To further investigate the effect of hotel size, hotel rating, social media experience and satisfaction from the use of social media on social media adoption whilst taking into account all the predictor variables simultaneously, we run hierarchical regression analysis. In step 1 the control variable of respondents' position was introduced first, and in step 2 hotel size, hotel rating, social media experience and satisfaction from the use of social media were entered into the regression. Table 6 displays the results of the regression analysis.

Table 6 Results of hierarchical regression analysis (standardised beta coefficients) $(\mathrm{N}=60)$

\begin{tabular}{lcc}
\hline \multirow{2}{*}{ Variables } & \multicolumn{2}{c}{ Social media adoption } \\
\cline { 2 - 3 } $\begin{array}{l}\text { Control variable } \\
\quad \text { Position }\end{array}$ & Model 1 & Model 2 \\
Predictor variables & -.07 & -.00 \\
$\quad$ Hotel size & & \\
$\quad$ Hotel rating & & -.02 \\
$\quad$ Social media experience & & .12 \\
$\quad$ Satisfaction from the use of social media & & $.23^{*}$ \\
$R^{2}$ & .00 & $.63^{* * *}$ \\
$\Delta R^{2}$ & .00 & $.58^{* * *}$ \\
$\Delta F$ & .30 & $.58^{* * *}$ \\
$F$ & .30 & $17.17^{* * *}$ \\
\hline
\end{tabular}

Note: $* \mathrm{p}<.05 ; * * * \mathrm{p}<.001$.

The analysis yielded a statistically significant model $\left(F_{(5,49)}=13.87, \mathrm{p}<.001, R^{2}=.58\right)$ (see model 2) that explained the $58 \%$ of the total variance of the dependent variable of social media adoption. Contrary to $\mathrm{H} 1$, hotel size is not related to social media adoption $(\beta=-.02, \mathrm{p}>.05)$. Moreover, hotel rating does not predict the dependent variable $(\beta=.12, \mathrm{p}>.05)$. So, $\mathrm{H} 2$ is rejected. As predicted, the analysis resulted in two statistically significant predictors of social media adoption, namely social media experience $(\beta=.23, \mathrm{p}<.05)$ and satisfaction from the use of social media $(\beta=.63$, $\mathrm{p}<.001)$. So, H3 and H4 are supported. 


\section{Discussion}

The tourism sector has been largely affected by the proliferation in social media platforms use by consumers, as they have changed consumer behaviour and consequently the marketing practices used by organisations. It is unquestionable that organisations that want to attract new customers and enlarge their customer base should offer as much brand-related information as possible (Reino and Hay, 2011). Apparently, the use of social media marketing tools and applications provide organisations in different industries, including hotel industry, with the path to build and extend long-lasting customer relationships with their customers and stay connected anywhere and at any time (Armstrong and Kotler, 2015; Hofacker and Belanche, 2016). Given the importance and the opportunities that social media marketing can offer to hotels, the present study makes an attempt to address the issue of how hotels adopt social media as a powerful marketing and communication tool. It also tries to identify organisational factors that affect social media adoption rate by hotels, and provide empirical evidence on the relationship between social media use and hotel's performance.

The results of this survey reveal that hotels in Greece are increasingly deploying social media as part of their marketing strategy with different levels of sophistication. It is evident that Greek hotels have employed social media technologies mainly to communicate and integrate with customers. Although the level of social media penetration is rather high, a great number of hotels need to progress regarding their degree of social media use. Hotels with low levels of social media utilisation should realise the benefits of social media potential in order to compete in international markets, especially when Greece's basic international tourism markets, such as British and German, are very mature in ICTs (Buhalis and Deimezi, 2004).

Consistent with previous research (Dosi and Tzortzaki, 2017), the overwhelming majority of hotels in our study have primarily adopted Facebook, with TripAdvisor coming second in the frequency of use among small and medium-sized Greek hotels. A considerable number of hotel firms have not fully exploited the potential from social media use; therefore, hotels vary in the degree of online strategies adopted in different platforms. We also note that the vast majority of hotels deploy more than one platform simultaneously. The integration of multiple social media platforms can provide hotels with various benefits due to different characteristics of each platform. The usage of different social media platforms by hotel firms enables them to gain more access to clientele that use different types of social media to connect online. With regard to selection criteria, the survey concludes that the most important criteria for the selection of specific social media tools are the popularity and the importance of the platform, followed by their use from the rival hotels and the cost of employing them.

According to hoteliers' responses, the main objectives of using social media tools are to attract new customers, thus increase sales levels, nurture stronger relationships with customers, and get a better understanding of the customers' preferences. It seems that the majority of hoteliers concentrate on sales goals. Furthermore, our respondents stress the importance of social media in social interaction, communication, sharing and actively

participating in a network. Consequently, the findings assent that one of the primary objectives of an organisation when uses social media for marketing purposes is to facilitate active communication with customers and strengthen relationships with them (Buhalis and Deimezi, 2004). Lastly, the results of our study, in contrast to other studies 
(Weinberg and Pehlivan, 2011), do not support the findings that the use of a specific social media tool is related to the accomplishment of specific objectives.

Since social media analytics provide a range of different benefits for organisations (Sterne, 2010; Kurniawati et al., 2013; Holsapple et al., 2014), the vast majority of the respondents deploy social media-analytics (SMA) in their hotels to assess the effectiveness of social media engagement and evaluate their results against objectives pursued. Though, a large percentage of hotels do not use e-metrics tools probably because they are unaware of the range of potential benefits of feedback and insight gained from e-analytics or they are unfamiliar with their usage. The effective deployment of SMA applications to track social media activities is crucial for social media marketing decision-making due to their impact on business. Tracking social media usage can also help small and medium hotels to improve their social media presence compared to competitors.

As reported in the relevant literature (Law and Jogaratnam, 2005; Buhalis, 2003), hoteliers are somewhat reluctant to adopt new technologies, including social media tools, compared to managers in other tourism enterprises. Hence, the acknowledgement of the critical factors that enhance social media use may stimulate the employment with social media tools from hoteliers for marketing and selling purposes. Our results indicate that hotels use social media tools regardless their size, expressed by the number of employees that a hotel employs, and star rating. Although previous studies have concluded that size is a critical factor of technology adoption due to a number of adoption barriers related to small businesses, such as resource barriers, unfamiliarity with technology, negative perception about their usefulness, the results of our study do not support these findings. This can be attributed to special characteristics of social media that are low cost, and basic IT knowledge requirements (Derham et al., 2011). Though unlike other pertinent findings, our results imply that hotel size and hotel rating should not be considered obstacles for the integration of social media tools in hotel marketing and communication plans. The view that benefits can only be accrued by large organisations is not accurate, and hotel practitioners must be aware that small and medium organisations can also reap these benefits as well (Meske and Stieglitz, 2013). It is also important for small businesses to understand that the constant managing and update of the content of social media platforms can be a time-consuming activity for managers-owners of a hotel, so employing a professional or even outsource their social media management could be seriously considered by hotel managers.

In addition, the results demonstrate that the degree of social media adoption is significantly affected by hotel previous experience with social media tools, while satisfaction from their use is the strongest predictor of the extent of social media use. With regards to satisfaction, a great percentage of respondents report high levels of satisfaction regarding the use of social media tools. A smaller though significant percentage of hotel managers express no satisfaction with the current use of social media tools. The reasons for that could be attributed to hotels failing to deploy the full potential of social media tools capabilities. Hotels do not often use social media analytics applications effectively to measure social media performance. Concluding, one of the main findings here is that the degree of social media adoption is mainly influenced by personal perceptions. Managers who perceive a high level of satisfaction regarding its use have higher propensity towards the continuing implementation of a social media plan.

Lastly, we confirm the positive relation between the extent of social media use and hotel performance (Ainin et al., 2012; Stone et al., 2007). It is of the utmost importance 
that even small hotels that have adopted social media have gained all the benefits in marketing and communication associated with social media use. In the light of this relationship, hotels should incorporate social media in their marketing strategy to a greater extent in order to grip the full range of the benefits that social media provide. We can also infer from the results that hotels recognise the benefits associated with social media deployment, and that is reflected in the positive relationship between social media use and hotel performance.

\subsection{Study strengths, practical implications, limitations and future research}

The above results provide new findings and directions for small and medium-sized hotel marketers and hoteliers who want to embrace the new social media marketing trends and develop a dynamic online presence. The empirical evidence from this study offers a deeper understanding of the factors that influence social media use, and enhances confidence in marketing managers, hotel marketers and hoteliers to further stimulate the use of social media tools as they contribute significantly to the increase of organisational performance. Merely introducing ICT elements may not be enough to boost hotel financial and non-financial performance (Sirirak et al., 2011). In particular, the degree of social media adoption is what matters the most to enhance performance levels.

Knowing the factors that accelerate the use of social media tools for marketing and communication purposes can serve strategically in the following directions: to an increase of hotel performance, profitability and customer satisfaction. It can also contribute to an enhancement of tourism related benefits for the local economy in a sustainable manner. Thereafter, the ignorance of the factors that ensure sufficient social media use, and consequently the failure of small and medium hotels to engage in social media platforms and implement online booking strategies, may put them at a competitive disadvantaged position.

The findings support that social media deployment can both affect the financial and non-financial performance of small and medium hotels, as it is directly linked to hotel online communication strategy and marketing strategy. The contribution of social media use in hotel performance can serve as a facilitator of social media deployment, especially for small and medium hotels in Greece. Thereafter, the increased use of social media platforms may help small and medium hotels to reduce their total dependence on the distribution channel members (e.g., tour operators) for reaching target markets and communicate with customers, an issue that is particularly pronounced in Greek hotels (Buhalis, 2000) and even more noticeable in Crete where local tour operators exercise great power over hoteliers as they control the charter flights market (Fountoulaki et al., 2015). Hence, enhancing social media deployment offers to small and medium hotels in Greece direct booking opportunities, the potential to engage in new online distribution channels for bookings/reservations and new avenues for growth in international and global markets, thus increasing the bargaining power of hotels over traditional travel agencies and tour operators. On the other hand, keeping in mind that Crete is considered an insular and peripheral travel destination, which accounts for the huge dependence on intermediaries with great bargaining power, hoteliers are often forced to lower their prices while improving the quality of their services, and operating in a competitive local market where discounting in price is essential to attract visitors (Buhalis, 1999). As such, our results strongly indicate that fostering the level of social media use could also be 
beneficial especially for hotels at peripheral destinations to attract the desired customers. In this way, tourism development of a peripheral destination can be assured and the destination can reap all the relevant benefits with the appropriate use of social media tools.

From a practical perspective, the use of social media tools enables hotels to attract the desired travel market segments reducing the reliance on tour operators while ensuring hotel economic performance. Having in mind that social media platforms constitute the primary source of travel-related information used by customers in the hotel industry, hotels that wishing to increase sales and attract new guests have to manage successfully their online presence and communication. Though, if hotel management puts emphasis on non - financial organisational performance, simply by introducing social media does not guarantee enhanced levels of customer loyalty or brand awareness, while the intensity of information and communication technology usage and the degree of social media adoption may provide valuable help in this direction. It is crucial for hotel firms to create and deliver appropriate content through social media platforms for different segments of users in order for social media to enhance the communication effectiveness (Tiago et al., 2018).

Furthermore, due to transparency and price comparisons, the role of consumer is certainly strengthened (Buhalis and Zoge, 2007) that makes it imperative for hotels to customise their products and services to tourism needs in order to remain competitive. Social media redefines the source of competitive advantage, giving the opportunity to hoteliers to be innovative and differentiate their offerings rather than competing over price, while offering customised and value-added services to customers. Another important implication of this research regarding the factors that enhance the degree of social media use, relates to the valuable and instant information a hotel can gather directly from customers about the service attributes that are important drivers of their buying intention, as well as the level of fulfilment. This has direct implications associated with the development of customer expectations. Marketing activities through social media form expectations of service quality to customers about products and services provided by hotels. Hotel success to exceed customers' expectations and generate satisfied customers is extremely important for the hotel success and survival (Ahmad et al., 2018). So, it is imperative that hotel firms carefully create and manage expectations of service quality through social media use.

Additionally, the research findings also provide useful implications not only for the hotel management, but also for the social media service providers. The improved knowledge about hotel managers' perceptions and attitudes towards social media use, and more specifically about the importance they attach to certain selection criteria, can help social media service providers to increase the value delivered from the social media services they provide to hotels. Social media providers should be aware that the cost associated with the use of social media is the least important selection criteria for hotels. What is more, the findings are decisive for policy makers, as they stress the need for a central strategic planning regarding the use of social media by Greek hotels, as it can contribute and strengthen the online presence of the country worldwide and also its competitiveness and success. Collaboration between the hotel industry and the government is needed to promote policies, such as training and funding, that will accelerate the diffusion and the degree of social media deployment in hotels.

However, a few limitations of our study should also be taken into consideration. Although our sample was not high enough to ensure enhanced statistical power, smaller 
samples may be acceptable if the research variables are reliable and the proposed model in not very complex (e.g., Bollen, 1990; Iacobucci, 2010). Furthermore, systematic errors due to key informants' tendency to overreporting or underreporting organisational-level phenomena as a function of their position in the organisation, their organisational tenure, and their personal characteristics (i.e., demographic data, personality), might have distorted their inferences towards study's organisational-level constructs and subsequently the relationships between the predictors and the criteria (see Bagozzi et al., 1991). So, research in this field should address the issue of common method biases (Podsakoff et al., 2003) and incorporate different sources of ratings such as employees, hotel clientele.

Concluding, a thorough investigation of the determinants of the degree of SM use in the hotel industry can be promising and serve for further research. First, although the results of our study can be used to advance our understanding of the organisational factors that influence social media use, future research should continue to examine the impact of size and star rating on the adoption of social media use, as well as the development and testing of a more integrated framework elaborating not only on additional organisational factors, but also managerial, technological and environmental factors relevant to hotel industry. Additionally, the orientation of future attempts should be focused on examining determinants of the level of involvement in each of the social media platform separately. Secondly, the present study can serve as a starting point for exploring further the type of social media tools adopted by hotels in order to achieve their marketing and communication objectives. Thirdly, future research should be directed towards whether the decision to engage in social media tools based on specific selection criteria is related to increased levels of organisational effectiveness. For example, it would be of great interest to examine whether the selection of social media tools that have been selected in terms of cost or functionality, may be a misleading practice that does not serve the marketing and communication objectives of a hotel. Finally, to address the research problem more in depth, future research should be conducted into different industries, other contexts and other countries. Since social media adoption may depend on whether the hotels are sea side or city hotels or whether they are luxury or economy hotels (Tajvidi and Karami, 2017), future research should be based on these elements to broaden our knowledge of the impact of social media adoption on firm performance.

Despite its limitations, the current study provides a starting point for understanding factors that enhance the use of social media strategies in a hotel context. Social media engagement and managing user-generated content on social media platforms comprise great challenges for hotel industry professionals. Along with traditional means, social media can provide hotels with the opportunity to successfully implement the marketing and communication strategy for the benefit of the hotel.

\section{References}

Ahmad, S.Z., Bakar, A.R.A. and Ahmad, N. (2018) 'Social media adoption and its impact on firm performance: the case of the UAE', International Journal of Entrepreneurial Behavior \& Research, Vol. 25, No. 1, pp.84-111.

Ainin, S., Bahri, S., Faziharudean, T.M. and Salleh, N.A.M. (2012) 'Impact of business process outsourcing practices on financial performance', Asian Journal of Information Technology, Vol. 11, No. 2, pp.56-64. 
Ainin, S., Parveen, F., Moghavvemi, S., Ismawati, N., Jaafar, N., MohdShuib, N. (2015) 'Factors influencing the use of social media by SMEs and its performance outcomes', Industrial Management \& Data Systems, Vol. 115, No. 3, pp.570-588.

Ajzen, I. (1991) The Theory of Planned Behavior. Organization Behavior and Human Decision Processes, Vol. 50, No. 2, pp.179-211, Academic Press, Inc..

Andzulis, J.M., Panagopoulos, N.G. and Rapp, A. (2012) 'A review of social media and implications for the sales process', Journal of Personal Selling and Sales Management, Vol. 32, No. 3, pp.305-316.

Armstrong, G. and Kotler, P. (2015) Marketing: An Introduction, 12th ed., Pearson Prentice-Hall, London.

Arpaci, I., Yardimci, Y.C., Ozkan, S. and Turetken, O. (2012) 'Organizational adoption of information technologies: a literature review', International Journal of eBusiness and eGovernment Studies, Vol. 4, No. 2, pp.37-50.

Ashley, C. and Tuten, T. (2015) 'Creative strategies in social media marketing: An exploratory study of branded social content and consumer engagement', Psychology \& Marketing, Vol. 32, No. 1, pp.15-27.

Baghirov, F., Zhang, Y. and Hashim, N. (2019) 'Facebook fan page management for global airlines', Tourism Review, Vol. 74, No. 3, pp.532-546.

Bagozzi, R.P., Yi, Y. and Phillips, L. W. (1991) 'Assessing construct validity in organizational research', Administrative Science Quarterly, Vol. 36, pp.421-458.

Bahja, F., Cobanoglu, C., Verezina, K. and Lusby, C. (2018) 'Factors influencing cruise vacations: the impact of online reviews and environmental friendliness', Tourism Review, Vol. 74, No. 3, pp.400-415.

Baker, J. (2012) 'The technology-organization-environment framework', in Dwivedi, Y.K. et al. (Eds.): Information Systems Theory, pp.231-245, Springer New York, New York.

Bogea, F. and Brito, E.Z. (2018) 'Determinants of social media adoption by large companies', Journal of Technology Management and Innovation, Vol. 13, No. 1, pp.11-18.

Bollen, K.A. (1990) 'Overall fit in covariance structure models: two types of sample size effects', Psychological Bulletin, Vol. 107, No. 2, pp.256-259.

Buhalis, D. (1993) 'Regional integrated computer information reservation management systems (RICIRMS) as a strategic tool for the small and medium tourism enterprises', Tourism Management, Vol. 14, No. 5, pp.366-378.

Buhalis, D. (1999) 'Limits of tourism development in peripheral destinations: problems and challenges', Tourism Management, Vol. 20, No. 2, pp.183-185.

Buhalis, D. (2000) 'Information technology in tourism: past, present and future', Tourism Recreation Research, Vol. 25, No. 1, pp.41-58.

Buhalis, D. (2003) eTourism Information Technology for Strategic Tourism Management, Prentice Hall, London.

Buhalis, D. and Deimezi, O. (2004) 'E-tourism developments in Greece: information communication technologies adoption for the strategic management of the Greek tourism industry', Tourism and Hospitality Research, Vol. 5, No. 2, pp.103-130.

Buhalis, D. and Law, R. (2008) 'Progress in information technology and tourism management: 20 years on and 10 years after the internet - the state of etourism research', Tourism Management, Vol. 29, No. 4, pp.609-623.

Buhalis, D. and Sinatra, Y. (2019) 'Real-time co-creation and nowness service: lessons from tourism and hospitality', Journal of Travel \& Tourism Marketing, Vol. 36, No. 5, pp.563-582.

Buhalis, D. and Zoge, M. (2007) 'The strategic impact of the internet on the tourism industry', in Sigala, M., Mich, L. and Murphy, J. (Eds.): Information and Communication Technologies in Tourism, pp.481-492, Springer, Wien.

Cantallops, A.S. and Salvi, F. (2014) 'New consumer behavior: a review of research on eWOM and hotels', International Journal of Hospitality Management, Vol. 36, pp.41-51. 
Chang, C.C. (2013) 'Examining users' intention to continue using social network games: a flow experience perspective', Telematics and Informatics, Vol. 30, No. 4, pp.311-321.

Chikandiwa, S.T., Contogiannis, E. and Jembere, E. (2013) 'The adoption of social media marketing in South African banks', European Business Review, Vol. 25, No. 4, pp.365-380.

Chu, S.C. and Kim, Y. (2011) 'Determinants of consumer engagement in electronic word-of-mouth (eWOM) in social networking sites', International Journal of Advertising, Vol. 30, No. 1, pp.47-75.

Colliander, J. and Dahlén, M. (2011) 'Following the fashionable friend: the power of social media', Journal of Advertising Research, Vol. 51, No. 1, pp.313-320.

Constantinides, E. (2009) 'Social media/web 2.0 as marketing parameter: an introduction', 8th International Congress Marketing Trends.

Culnan, M.J., McHugh, P. and Zubillaga, G.I. (2010) 'How large U.S. companies can use Twitter and other social media to gain business value', MIS Quarterly Executive, Vol. 9, No. 4, pp.243-259.

Danias, K. and Kavoura, A. (2013) 'The role of social media as a tool of a company's innovative communication activities', The Makopolska Schools of Economics in Tarnow Research Papers Collection, Vol. 23, No. 2, pp.75-83.

Davis, F.D. (1989) 'Perceived usefulness, perceived ease of use, and user acceptance of information technology', MIS Quarterly, Vol. 13, No. 3, pp.319-340.

Derham, R., Cragg, P. and Morrish, S.C. (2011) 'Creating value: an SME and social media', Paper presented at the Pacific Asia Conference on Information Systems. PACIS 2011: Quality Research in Pacific Asia, 7-11 July 2011. Brisbane, Queensland, Australia.

Dosi, C. and Tzortzaki, A.M. (2017) 'Managing social media as a marketing tool in the Greek business environment', International Journal of Decision Science, Risk and Management, Vol. 7, Nos. 1-2, pp.48-69.

Drury, G., (2007) 'Opinion piece: social media: Should marketers engage and how can it be done effectively?', Journal of Direct, Data and Digital Marketing Practice, Vol. 9, No. 3, pp.274-277.

Escobar-Rodriquez, T. and Carvajal-Trujillo, E. (2013) 'An evaluation of Spanish hotel websites: Informational vs relational strategies', International Journal of Hospitality Management, Vol. 3, No. 1, pp.228-239.

Ferrer, E., Bousono, C., Jorge, J., Lora, L., Miranda, E. and Natalizio, N. (2013) 'Enriching social capital and improving organizational performance in the age of social networking', International Journal of Information, Business and Management, Vol. 5, No. 2, pp.94-109.

Filieri, R. and McLeay, F. (2013) 'E-WOM and accommodation: an analysis of the factors that influence travelers' adoption of information from online reviews', Journal of Travel Research, Vol. 53, No. 1, pp.44-57.

Fischer, C.S. (2009) 'The 2004 GSS finding of shrunken social networks: an artifact?', American Sociological Review, Vol. 74, No. 4, pp.657-69.

Fountoulaki, P., Leue, M.C. and Jung, T. (2015) 'Distribution channels for travel and tourism: the case of Crete', in Tussyadiah, I and Inversini, A. (Eds): Information and Communication Technologies in Tourism, Springer International Publishing, Vienna, New York.

Foux, G. (2006) 'Consumer generated media: get your customers involved', Brand Strategy, Vol. 8, pp.38-39.

Frambach, R.T. and Schillewaert, N. (2002) 'Organizational innovation adoption: a multi-level framework of determinants and opportunities for future research', Journal of Business Research, Vol. 55, No. 2, pp.163-176.

Gallaugher, J.M. and Ransbotham, S. (2011) 'Social media and customer dialog management at Starbucks', MIS Quarterly Executive, Vol. 9, No. 4, pp.197-212. 
Gangwar, H., Date, H. and Ramaswamy, R. (2015) 'Understanding determinants of cloud computing adoption using an integrated TAM-TOE model', Journal of Enterprise Information Management, Vol. 28, No. 1, pp.107-130.

Garrido-Moreno, A. and Lockett, N. (2016) 'Social media use in European hotels: benefits and main challenges', Tourism and Management Studies, Vol. 12, No. 1, pp.172-179.

Gilbert, D.C., (1996) 'Relationship marketing and airline loyalty schemes', Tourism Management, Vol. 17, No. 8, pp.575-582.

Goyette, I., Ricard, L., Bergeron, J. and Marticotte, F. (2010) 'E-WOM scale: word-of-mouth measurement scale for e-services context', Canadian Journal of Administrative Sciences, Vol. 27, No. 1, pp.5-23.

Gretzel, U., Yoo, K.H. and Purifoy, M. (2007) Online Travel Review Study: Role and Impact of Online Travel Reviews, Laboratory for Intelligent Systems in Tourism, TX.

Gupta, R. and Brooks, H. (2013) Using Social Media for Global Security, Wiley Publishing.

Hackler, D. and Saxton, G.D. (2007) 'The strategic use of information technology by nonprofit organizations: increasing capacity and untapped potential', Public Administration Review, Vol. 67, No. 3, pp.474-487.

Ham, S., Kim, W. and Jeong, S. (2005) 'Effect of information technology on performance in upscale hotels', International Journal of Hospitality Management, Vol. 24, No. 2, pp.281-294.

He, W., Wang F-K., Chen, Y. and Zha, S. (2015) 'An exploratory investigation of social media adoption by small businesses', Information Technology and Management, Vol. 18, pp.149-160.

Hernon, P. and Whitman, J.R. (2001) Delivering Satisfaction and Service Quality: A Customer-Based Approach for Libraries, American Library Association, Chicago.

Hofacker, C.F. and Belanche, D. (2016) 'Eight social media challenges for marketing managers'. Spanish Journal of Marketing - ESIC, Vol. 20, No. 2, pp.73-80.

Holsapple, C., Hsiao, S-H and Pakath, R. (2014) 'Business social media analytics: definition, benefits and challenges', Americas Conference on Information Systems (AMCIS) 2014, Savannah, GA, USA.

Iacobucci, D. (2010) 'Structural equation modeling: fit indices, sample size, and advanced topics', Journal of Consumer Psychology, Vol. 20, No. 1, pp.90-98.

Inversini, A. and Masiero, L. (2014) 'Selling rooms online: the use of social media and online travel agents', International Journal of Contemporary Hospitality Management, Vol. 26, No. 2, pp.272-292.

Jeong, M., Oh, H. and Gregorie, M. (2003) 'Conceptualizing web site quality and its consequences in the lodging industry', International Journal of Hospitality Management, Vol. 22, No. 2, pp.161-175.

Kapiki, S. (2012) 'Current and future trends in tourism and hospitality. The case of Greece', International Journal of Economic Practices and Theories, Vol. 2, No. 1, pp.1-12.

Kaplan, A. and Haenlein, M. (2010) 'Users of the world unite! The challenges and opportunities of social media', Business Horizons, Vol. 53, No. 1, pp.59-68.

Khalil, O. and Elkordy, M.M. (1999) 'The relationship between user satisfaction and systems usage: empirical evidence from Egypt', Journal of End User Computing, Vol. 11, No. 2, pp.21-28.

Kietzmann, J.H., Hermkens K., McCarthy, I.P. and Silvestre, B.S., (2011) 'Social media? Get serious! Understanding the functional building blocks of social media', Business Horizons, Vol. 54, No. 3, pp 241-251.

Kim, A. and Ko, E. (2012) 'Do social media marketing activities enhance customer equity? An empirical study of luxury fashion brand', Journal of Business Research, Vol. 65, No. 10, pp.1480-1486. 
Kropczynski, J. and Nah, S. (2011) 'Virtually networked housing movement: hyperlink network structure of housing social movement organizations', New Media \& Society, Vol. 13, pp.689-703.

Kumar, V., Chattaraman, V., Neghina, C., Skiera, B., Aksoy, L., Buoye, A. and Henseler, J. (2013) 'Data-driven services marketing in a connected world', Journal of Service Management, Vol. 24, No. 3, pp.330-352.

Kurniawati, K., Shanks, G. and Bekmamedova, N. (2013) 'The business impact of social media analytics', Proceedings of the 21st European Conference on Information System, Utrecht, The Netherlands, pp.48-61.

Kwok, L. and Yu, B. (2013) 'Spreading social media messages on Facebook: an analysis of restaurant business-to-consumer communications', Cornell Hospitality Quarterly, Vol. 54, No. 1, pp. 84-94.

Law, R., Qi, S. and Buhalis D. (2010) 'Progress in tourism management: a review of website evaluation in tourism research', Tourism Management, Vol. 31, No. 3, pp.297-313.

Law, R. and Jogaratnam, G. (2005) 'A study of hotel information technology applications', International Journal of Contemporary Hospitality Management, Vol. 17, No. 2, pp.170-180.

Lebherz, P.R. (2011) Relevant Factors for the Impact of Social Media Marketing Strategies: Empirical Study of the Internet Travel Agency Sector, Bachelor thesis.

Lee-Kelley, L., Gilbert, D. and Mannicom, R. (2003) 'How e-CRM can enhance customer loyalty?', Marketing Intelligence \& Planning, Vol. 21, No. 4, pp.239-248.

Leung, D., Law, R., van Hoof, H. and Buhalis D. (2013) 'Social media in tourism and hospitality: a literature review', Journal of Travel \& Tourism Marketing, Vol. 30, Nos. 1-2, pp.3-22.

Leung, X.Y., Bai, B. and Stahura, K.A. (2015) 'The marketing effectiveness of social media in the hotel industry: a comparison of Facebook and Twitter', Journal of Hospitality \& Tourism Research, Vol. 39, No. 2, 147-169.

Liang, T.P. and Turban, E. (2011) 'Introduction to Special issue social commerce: a research framework for social commerce', International Journal of Electronic Commerce, Vol. 16, No. 2, pp.5-13.

Litvin, S.W., Goldsmith, R.E. and Pan, B. (2008) 'Electronic word-of-mouth in hospitality and tourism management', Tourism Management, Vol. 29, No. 3, pp.458-468.

Mandal, D. and McQueen, R.J. (2012) 'Extending UTAUT to explain social media adoption by microbusiness', International Journal of Managing Information Technology, Vol. 4, No. 4, pp.1-11.

Mayfield, A. (2006) What is Social Media?. [online] http://www.icrossing.com/uk/sites/default/ files_uk/insight_pdf_files/What $\% 20$ is\%20Social\%20Media_iCrossing_ebook.pdf (accessed 19 November 2018).

McAfee, A.P. (2006) 'Enterprise 2.0: The dawn of emergent collaboration', Engineering Management Review, Vol. 34, No. 3, p.38.

Meske, C. and Stieglitz, S. (2013) 'Adoption and use of social media in small and medium-sized enterprises', 6th Practice Driven Research on Enterprise Transformation (PRET), Lecture Notes in Business Information Processing (LNBIP), pp.61-75.

Michaelidou, N., Siamagka, N.T. and Christodoulides, G. (2011) 'Usage, barriers and measurement of social media marketing: an explanatory investigation of small and medium B2B brands', Industrial Marketing Management, Vol. 40, No. 7, pp.1153-1159.

Minghetti, V. and Buhalis, D. (2010) 'Digital divide and tourism: bridging the gap between markets and destinations', Journal of Travel Research, Vol. 49, No. 3, pp.1-15.

Mistilis, N., Buhalis, D. and Gretzel, U. (2014) 'Future edestination marketing perspective of an australian tourism stakeholder network', Journal of Travel Research, Vol. 53, No. 6, pp.778-790.

Molla, A. and Heeks, R. (2007) 'Exploring e-commerce benefits for businesses in a developing country', The Information Society, Vol. 23, No. 2, pp.95-108. 
Munar, A.N. (2011) 'Tourist-created content: rethinking destination branding', International Journal of Culture, Tourism and Hospitality Research, Vol. 5, No. 3, pp.291-305.

Nassar, M. (2012) 'An investigation of hoteliers' attitudes toward the use of social media as a branding tool', International Journal of Marketing Studies, Vol. 4, No. 4, pp.93-105.

Ndekwa, A. and Katunzi, T.M. (2016) 'Small and medium tourist enterprises and social media adoption: empirical evidence from Tanzanian tourism sector', International Journal of Business and Management, Vol. 11, No. 4, pp.71-80.

Neti, S. (2011) 'Social media and its role in marketing', International Journal of Enterprise Computing and Business Systems, Vol. 1, No. 2, pp.1-15.

Neuhofer, B., Buhalis, D. and Ladkin, A. (2014) 'A typology of technology-enhanced tourism experiences', International Journal of Tourism Research, Vol. 16, No. 4, pp.3040-350.

Nikou, S.A. and Economides, A.A. (2015) 'The effects of perceived mobility and satisfaction on the adoption of mobile-based assessment', International Conference on Interactive Mobile Communication Technologies and Learning (IMCL), pp.167-171.

Nikraftar, T. and Hosseini, E. (2016) 'Factors affecting entrepreneurial opportunities recognition in tourism small and medium sized enterprises', Tourism Review, Vol. 71, No. 1, pp.6-17.

Noone, B.M., McGuire, K.A. and Rohlfs, K.V. (2011) 'Social media meets hotel revenue management: opportunities, issues and unanswered questions', Journal of Revenue and Pricing Management, Vol. 10, No. 4, pp.293-305.

Nunnally, J.C. (1978) Psychometric Theory, McGraw Hill, New York.

O'Conor, p. (2010) 'Managing a hotel's image on TripAdvisor', Journal of Hospitality Marketing and Management, Vol. 19, No. 7, pp.754-772.

Odoom, R., Anning-Dorson, T. and Acheampong, G. (2017) 'Antecedents of social media usage and performance benefits in small- and medium-sized enterprises (SMEs)', Journal of Enterprise Information Management, Vol. 30, No. 3, pp.383-399.

Oliveira, T. and Martins, M.F. (2011) 'Literature review of information technology adoption models at firm level', The Electronic Journal of Information Systems Evaluation, Vol. 14, No. 1, pp.110-121.

Paraskevas, A., Katsogridakis, I., Law, R. and Buhalis, D. (2011) 'Search engine marketing: transforming search engines into hotel distribution channels', Cornell Hospitality Quarterly, Vol. 52, No. 2, pp.200-208.

Park, E. and del Pobil, A.P. (2013) 'Modeling the user acceptance of long-term evolution services', Ann. Telecommun, Vol. 68, No. 5, pp.307-415.

Parveen, F. (2012) 'Impact of social media usage on organizations', PACIS Proceedings. pp.192-202.

Parveen, F., Jaafar, N.I. and Ainin, S. (2015) 'Social media usage and organizational performance: Reflections of Malaysian social media managers', Telematics and Informatics, Vol. 32, No. 1, pp.67-78.

Podsakoff, P.M., MacKenzie, S.B., Lee, J. and Podsakoff, N.P. (2003) 'Common methods biases in behavioral research: a critical review of the literature and recommended remedies', Journal of Applied Psychology, Vol. 88, No. 5, pp.879-903.

Porter, M. (2001) 'Strategy and the internet', Harvard Business Review, Vol. 79, No. 3, pp.63-78.

Pradiptarini, C. (2011) 'Social media marketing: measuring its effectiveness and identifying the target market', Journal of Undergraduate Research, Vol. 14, pp.1-10.

Radwan, H.R.I. (2016) 'Evaluating the effectiveness of social media as a marketing tool in the hotel sector: a case study on four and five star hotels in Makkah, Saudi Arabia', Journal of Faculty of Tourism and Hotels, Fayoum University, Vol. 8, No. 1, 151-169.

Rahab, R. and Hartono, J. (2012) 'Adoption of information technology on small businesses: the role of environment, organizational and leader determinant', International Journal of Business, Humanities and Technology, Vol. 2, No. 4, pp.60-66. 
Reino, S. and Hay, B. (2011) 'The use of YouTube as a tourism marketing tool', Proceedings of the 42nd Annual Travel \& Tourism Research Association Conference, London, Ontario, Canada., Vol. 42.

Rodriguez, M., Ajjan, H. and Peterson, R. M. (2014) 'CRM/ social media technology: impact on customer orientation process and organizational sales performance', Journal of Marketing Development and Competitiveness, Vol. 8, No. 1, pp.85-97.

Rogers, E.M. (2003) Diffusion of Innovations, Free Press, New York.

Seidler, J. (1974) 'On using informants: a technique for collecting quantitative data and controlling for measurement error in organizational analysis', American Sociological Review, Vol. 39, No. 12, pp.816-831.

Saravanakumar, M. and Sugantha-Lakshmi, T. (2012) 'Social media marketing', Life Science Journal, Vol. 9, No. 4, pp.4444-4451.

Shook, S.R., Zhang, Y., Braden, R. and Baldridge, J. (2002) 'The use of e-business in the Pacific Northwest secondary forest products industry', Forest Products Journal, Vol. 52, No. 1, pp.59-66.

Siamagka, N.T., Christodoulides, G, Michaelidou, N and Valvi, A. (2015) 'Determinants of social media adoption by B2B organizations', Industrial Marketing Management, Vol. 51, pp.89-99.

Sigala, M. (2011) 'eCRM 2.0 applications and trends: the use and perceptions of Greek tourism firms of social networks and intelligence', Computers in Human Behavior, Vol. 27, No. 2, pp.655-661.

Sirirak, S., Islam, N. and Khang, D.B. (2011) 'Does ICT adoption enhance hotel performance?', Journal of Hospitality and Tourism Technology, Vol. 2, No. 1, pp.34-49.

Sparks, B.A. and Browning, V. (2011) 'The impact of online reviews on hotel booking intentions and perception of trust', Tourism Management, Vol. 32, No. 6, pp.1310-1323.

Spencer, A.J., Buhalis, D. and Moital, M. (2012) 'A hierarchical model of technology adoption for small owner-managed travel firms: an organizational decision-making and leadership perspective', Tourism Management, Vol. 33, No. 5, pp.1195-1208.

Spita, M. (2017) Social Media as a Marketing Tool and Its Use in the Hospitality Industry, Master Thesis, Hellenic Open University, Master in Business Administration (MBA), Patras, Greece.

Statista.com (2018) Social Media Usage Worldwide [online] https://www.statista.com/study/12393/ social-networks-statista-dossier/ (accessed 21 November 2018).

Sterne, J.S. (2010) Social Media Metrics: How to Measure and Optimize Your Marketing Investment, Wiley, Hoboken, N.J.

Stone, R.W., Good, J.D. and Eveleth, L.B. (2007) 'The impact of information technology on individual and firm marketing performance', Behaviour and Information Technology, Vol. 26, No. 6, pp.465-482.

Straub, E.T. (2009) 'Understanding technology adoption: theory and future directions for informal learning', Communication Research, Vol. 79, No. 2, pp.359-378.

Tajvidi, R. and Karami, A. (2017) 'The effect of social media on firm performance', Computers in Human Behavior, pp.1-10.

Tiago, F., Couto, J., Faria, S. and Borgew-Tiago, T. (2018) 'Cruise tourism: social media content and network structures', Tourism Review, Vol. 73, No. 4, pp.433-447.

Tornatzky, L.G. and Fleischer, M. (1990) The Processes of Technological Innovation, Lexington Books, Lexington.

TripAdvisor (2018) About TripAdvisor [online] https://tripadvisor.mediaroom.com/UK-about-us (accessed 29 November 2018).

Trusov, M., Bucklin, R.E. and Pauwels, K. (2009) 'Effects of word-of-mouth versus traditional marketing, findings from an internet social networking site', Journal of Marketing, Vol. 73, No. 5, pp.90-102.

Varkaris, E. and Neuhofer, B. (2017) 'The influence of social media on thee consumers' hotel decision journey', Journal of Hospitality and Tourism Technology, Vol. 8, No. 1, pp.101-118. 
Venkatesh, V. and Davis, F.D. (2000) 'A theoretical extension of the technology acceptance model: four longitudinal field studies', Management Science, Vol. 46, No. 2, pp.186-204.

Venkatesh, V., Morris, M.G., Davis, F.D. and Davis, G.B. (2003) 'User acceptance of information technology: toward a unified view', MIS Quarterly, Vol. 27, No. 3, pp.425-478.

Verheyden, M. and Goeman, K. (2013) 'Does (company) size matter? Differences for social media usage for different purposes', Journal of Applied Quantitative Methods, Vol. 8, No. 4, pp.3-15.

Viglia, B, Minazzi, R. and Buhalis, D. (2016) 'The influence of e-word-of-mouth on hotel occupancy rate', International Journal of Contemporary Hospitality Management, Vol. 28, No. 9, pp.2035-2051.

Wamba, S.F. and Carter, L. (2014) 'Social media tools adoption and use by SMES: an empirical study', Journal of Organizational and End User Computing, Vol. 26, No. 2, pp.1-17.

Wang, W., Wu, W., Luo, J. and Lu, J. (2017) 'Information technology usage, motivation, and intention: a case of Chinese urban senior outbound travelers in the Yangtze River Delta region', Asia Pacific Journal of Tourism Research, Vol. 22, No. 1, pp.99-115.

Weinberg, B.D. and Pehlivan, E. (2011) 'Social spending: managing the social media mix', Business Horizons, Vol. 54, No. 3, pp.275-282.

Wikipedia (2018) Hotel Rating [online] https://en.wikipedia.org/wiki/Hotel_rating (accessed 29 November 2018).

WTTC (2018) Travel and Tourism Economic Impact 2018 [online] https://www.wttc.org//media/files/reports/economic-impact-research/regions-2018/world2018.pdf (accessed 19 November 2018).

Xiang, Z. and Gretzel, U. (2010) 'Role of social media in online travel information search', Tourism Management, Vol. 31, No. 2, pp.179-188.

Xiang, Z., Magnini, V.P. and Fesenmaier, D.R. (2015) 'Information technology and consumer behavior in travel and tourism: insights from travel planning using the internet', Journal of Retailing and Consumer Services, Vol. 22, No. 1, pp.244-249.

Yu, C.S. and Tao, Y.H. (2009) 'Understanding business-level innovation technology adoption', Technovation, Vol. 29, No. 2, pp.92-109.

Zorn, T.E., Flanagin, A.J. and Shoham, M.D. (2011) 'Institutional and noninstitutional influences on information and communication technology adoption and use among nonprofit organizations', Human Communication Research, Vol. 37, No. 1, pp.1-33. 